Jurnal Politico Vol. 19 No. 1, Maret 2019

Halaman 50-66. ISSN : p: 1829-6696, e:2549-4716

Web jurnal online: jurnal.unmuhjember.ac.id

By: Faisal Al Riza, Emy Kholifah R.

Effectiveness Of The Performance Of The Blood Management Agency (Bpbd) In Treatment Of

Post Earthquake Natural Disaster In Lombok Province Nusa Tenggara Barat.

\title{
EFFECTIVENESS OF THE PERFORMANCE OF THE BLOOD MANAGEMENT AGENCY (BPBD) IN TREATMENT OF POST EARTHQUAKE NATURAL DISASTER IN LOMBOK PROVINCE NUSA TENGGARA BARAT.
}

\author{
By: Faisal Al Riza, Emy Kholifah R.(correspondence author) \\ Program Studi Ilmu PemerintahanFakultas Ilmu Sosial dan Ilmu Politik \\ Universitas Muhammadiyah Jember \\ emykholifah25@gmail.com
}

Received: 5 Februari 2019, Revised: 23 Februari 2019, Accepted: 25 Februari 2019

\begin{abstract}
This study uses a performance evaluation used by the West Nusa Tenggara Provincial Disaster Management Agency to measure organizational performance after an earthquake. The research method used in this study is that qualitative research carried out in the research conducted is descriptive research that discusses the analysis of events. The unit of analysis in this study is the effectiveness of the performance evaluation of the Regional Disaster Management Agency of West Nusa Tenggara Province. The type of research used by the authors in this study is qualitative descriptive. Data collection techniques are interviews, observations and documents related to research. The data analysis technique in this study was carried out qualitatively. Objectives / goals / plans in achieving the goals, objectives, mission, organizational vision contained in the formulation of strategic planning (strategic planning) of an organization. Then, the results of the assessment that shows the results of systematic analysis and evaluation results based on performance indicators, which involve indicators of input, output, results, benefits, and changes. Performance measurement is used as a basis for achieving success and completion of implementation in accordance with the goals and objectives set in the framework of realizing the vision and mission. Stages of measuring organizational performance according to tactics starts from clarity of purpose, clarity of strategy, process of analysis and policy formulation, planning, planning programs, availability of facilities and infrastructure and a system of supervision and control. The results of this study explain the measurement system applied by the Regional Disaster Management Agency of West Nusa Tenggara Province has not been effective. Because the performance assessment carried out by the Regional Disaster Management Agency of the Province of West Nusa Tenggara is not systematically arranged and can only be accessed in the Government Agency Performance Accountability Report.

Keywords: Effectiveness, Performance, Performance Measurement
\end{abstract}


Jurnal Politico Vol. 19 No. 1, Maret 2019

Halaman 50-66. ISSN : p: 1829-6696, e:2549-4716

Web jurnal online: jurnal.unmuhjember.ac.id

By: Faisal Al Riza, Emy Kholifah R.

Effectiveness Of The Performance Of The Blood Management Agency (Bpbd) In Treatment Of

Post Earthquake Natural Disaster In Lombok Province Nusa Tenggara Barat.

\section{INTRODUCTION}

Lately, natural disasters that have happened continuously every day in the middle of Indonesia, West Nusa Tenggara Province, precisely on the island of Lombok, are earthquakes. Based on the value of the loss and the frequency of the occurrence of earthquake disasters, there is a significant increase Earthquake events are strongly influenced by natural factors because Lombok island is located between two earthquake generators from north and south, from the north there is a geological structure of faults flores while in the south there are indo-Australian subduction zones. Besides that earthquakes often occur in Lombok in previous years including 1956, 1970, 1972, 1978, 1979, 2000, and 2016, because lombok earthquakes often occur so that the Regional Disaster Management Agency (BPBD) was formed.

With the enactment of Law Number 24 of 2007 concerning Disaster Management, the implementation of disaster management is expected to be even better, because the government and regional governments are responsible for implementing disaster management. Disaster management is directed in a predisaster manner, during emergency response and post-disaster.

Provinces and districts / cities began to develop disaster management policies, strategies and operations in accordance with the direction of policy development at the national level. Disaster management efforts in the regions need to begin with the existence of regional policies aimed at tackling disasters in accordance with existing regulations. Strategies determined by regions in tackling disasters need to be adapted to regional conditions. National disaster management operations must be ensured to be effective, efficient and sustainable. To support the development of a disaster management system that includes policies, strategies and operations nationally including the central and regional governments, it is necessary to begin by knowing the extent to which the regulations related to disaster management in the regions are implemented. Based on the above background, the authors are interested in taking the title "The 
Jurnal Politico Vol. 19 No. 1, Maret 2019

Halaman 50-66. ISSN : p: 1829-6696, e:2549-4716

Web jurnal online: jurnal.unmuhjember.ac.id

By: Faisal Al Riza, Emy Kholifah R.

Effectiveness Of The Performance Of The Blood Management Agency (Bpbd) In Treatment Of

Post Earthquake Natural Disaster In Lombok Province Nusa Tenggara Barat.

Effectiveness of Performance of the Regional Disaster Management Agency (BPBD) in Natural Disaster Management Post Earthquake in Lombok, West Nusa Tenggara Province".

\section{LITERATURE REVIEW}

Performance effectiveness is interpreted as an ability to choose the right target in accordance with the goals set from the beginning. This opinion was supported by Danim (2004) who said that the effectiveness of group performance was related to the ability of members to choose or do something right for the common interest.

The effectiveness of performance will increase if someone has the skills and expertise that are in accordance with the demands of work. The effectiveness of individual performance can be measured from work skills, improvement in achievement, ability to adapt, and be able to deal with change (Bass and Daft, 1989).

Aspects of performance effectiveness

1. Performance skills

2. Increased work

3. Ability to compete

4. Adaptability

5. Resistance to change

Factors that affect effectiveness

1. Leadership style

2. Dependency

3. Friendship relations

4. Culture

5. Ability

6. Value system

Effectiveness Measurement

1. Clarity of purpose 
2. Clarity of strategy

3. Analysis process

4. Planning

5. Preparation of the program

6. Facilities and infrastructure

7. System of supervision and control

\section{RESEARCH METHODS}

The type of research used in this study is descriptive research type, namely the type of research that seeks to describe a phenomenon or event as it is, while the approach in this study is to use qualitative methods.

Clarity of Purpose

Implementation of disaster management in the post-disaster phase includes:

1. Rehabilitation through activities:

a. Improved disaster area environment

b. Repair of public infrastructure and facilities

c. Providing assistance for community housing improvements

d. Psychological social recovery and health services

e. Reconciliation and conflict resolution

f. Cultural socio-economic recovery

g. Restoring security and order

h. Recovery of government functions

i. Recovery of public service functions.

2. Reconstruction, carried out through better development activities, includes:

a. Rebuilding infrastructure and facilities

b. Rebuilding community social facilities

c. Rebuilding the socio-cultural life of the community

d. Application of appropriate design and use of better equipment and disaster resistance. 
Jurnal Politico Vol. 19 No. 1, Maret 2019

Halaman 50-66. ISSN : p: 1829-6696, e:2549-4716

Web jurnal online: jurnal.unmuhjember.ac.id

By: Faisal Al Riza, Emy Kholifah R.

Effectiveness Of The Performance Of The Blood Management Agency (Bpbd) In Treatment Of

Post Earthquake Natural Disaster In Lombok Province Nusa Tenggara Barat.

e. Participation and participation of social institutions and organizations, the business world, society, improving social, economic and cultural conditions

f. Improving the function of public services; and improvement of key services in the community.

Clarity Strategy

several strategies that can be done in order to increase disaster management capacity. In an effort to realize the goals and objectives of the NTB BPBD strategy, a number of strategies and policies were implemented including:

Strategy

1. Dissemination and facilitation for the formation of disaster resilient villages

2. Facilities and procurement of materials, goods and equipment and personnel for disaster emergency handling

3. Dissemination of safe schools / madrasas

4. Making office building facilities (communication room)

Policy

1. Coordination with District / City, District and Village Governments that are the target of the Tangguh Disaster Village

2. Coordination with the District / City governments affected by the disaster

3. Coordination with District / City and School Governments that are targeted by schools / Madrasas to be safe from disasters

4. Consultation with the Central Government and coordinate with disaster experts / experts

5. Coordinate with BNPB and BPBD NTB, prepare plans and budgets

6. Strengthen coordination within the internal BPBD throughout the NTB

7. Prepare planning, budgeting, monitoring and evaluation of disaster management.

Performance Planning

1. Planning for Disaster Victim Home Improvement 
Jurnal Politico Vol. 19 No. 1, Maret 2019

Halaman 50-66. ISSN : p: 1829-6696, e:2549-4716

Web jurnal online: jurnal.unmuhjember.ac.id

By: Faisal Al Riza, Emy Kholifah R.

Effectiveness Of The Performance Of The Blood Management Agency (Bpbd) In Treatment Of

Post Earthquake Natural Disaster In Lombok Province Nusa Tenggara Barat.

a. Assessment of Determination of the Number of Disaster Victims' Home Improvements

The assessment of the number of houses that need to be repaired or rebuilt (Disaster Victims Home Improvement) uses a methodology for verifying the level of damage to houses carried out by the Verification and Validation Team, which produces data per name and per home address (by name by address) according to the house damage category stated in the Decree of the Regent / Mayor.

b. The head of the district / city BPBD instructs BRI to open beneficiary community accounts based on the Decree of the Regent / Mayor regarding the determination of recipients of stimulant assistance to repair damaged houses.

c. The head of the district / city BPBD instructs BRI to debit the district / city BPBD account to the community account recipient of stimulant assistance for repairing damaged houses.

d. In order to guarantee participation, transparency and accountability, recipients of stimulant assistance data The facilitating team disseminated to the public about the implementation of public tests, the establishment of Pokmas, mechanisms and procedures for managing funds, work plans for the use of stimulant funds and reporting.

e. Public Tests are carried out by attaching data on recipients of damaged home stimulant assistance to village / kelurahan announcement boards to be observed and observed by the community. The community can submit objections and corrections to the data submitted to the District / City Verification and Validation Team through the village head / lurah

1. Planning for Disaster Victim Home Improvement

a. Assessment of Determination of the Number of Disaster Victims' Home Improvements

The assessment of the number of houses that need to be repaired or rebuilt (Disaster Victims Home Improvement) uses a methodology for verifying the level of damage to houses carried out by the Verification and Validation 
Jurnal Politico Vol. 19 No. 1, Maret 2019

Halaman 50-66. ISSN : p: 1829-6696, e:2549-4716

Web jurnal online: jurnal.unmuhjember.ac.id

By: Faisal Al Riza, Emy Kholifah R.

Effectiveness Of The Performance Of The Blood Management Agency (Bpbd) In Treatment Of

Post Earthquake Natural Disaster In Lombok Province Nusa Tenggara Barat.

Team, which produces data per name and per home address (by name by address) according to the house damage category stated in the Decree of the Regent / Mayor.

b. The head of the district / city BPBD instructs BRI to open beneficiary community accounts based on the Decree of the Regent / Mayor regarding the determination of recipients of stimulant assistance to repair damaged houses.

c. The head of the district / city BPBD instructs BRI to debit the district / city BPBD account to the community account recipient of stimulant assistance for repairing damaged houses.

d. In order to guarantee participation, transparency and accountability, recipients of stimulant assistance data The facilitating team disseminated to the public about the implementation of public tests, the establishment of Pokmas, mechanisms and procedures for managing funds, work plans for the use of stimulant funds and reporting.

e. Public Tests are carried out by attaching data on recipients of damaged home stimulant assistance to village / kelurahan announcement boards to be observed and observed by the community. The community can submit objections and corrections to the data submitted to the District / City Verification and Validation Team through the village head / lurah.

f. After going through the process of socialization and public testing, the Verification and Validation Team conducted a series of activities which included:

1. Technical validation of the level of damage (severely damaged, moderately damaged, lightly damaged) according to the criteria

a. Administrative validation according to home ownership data and identity of recipients of stimulant assistance

b. Based on the results of verification and validation, the verification and validation team provides recommendations to the Regent / Mayor to revise the Decree of the Regent / Mayor regarding recipients of stimulant assistance to repair damaged houses, if needed. Thus, in the event of an 
Jurnal Politico Vol. 19 No. 1, Maret 2019

Halaman 50-66. ISSN : p: 1829-6696, e:2549-4716

Web jurnal online: jurnal.unmuhjember.ac.id

By: Faisal Al Riza, Emy Kholifah R.

Effectiveness Of The Performance Of The Blood Management Agency (Bpbd) In Treatment Of

Post Earthquake Natural Disaster In Lombok Province Nusa Tenggara Barat.

error, it is possible to correct or withdraw money that already exists in the community account to be returned to the BPBD / City account.

c. The team of facilitators will facilitate the establishment of POKMAS through a community consultation mechanism. The establishment of community groups is carried out to encourage the realization of transparency and accountability at the community level receiving stimulant assistance. Pokmas are formed by considering the same damage criteria and the closest geographical distance so that they can help each other and strengthen social control. The number of community members is between 10 and 20 family heads, which are determined by the local village head / lurah.

d. iThe implementation of Home Improvement is carried out through a process of planning, implementation and supervision. During the planning process, the Pokmas opened a Pokmas account with 3 specimens (Chairperson, secretary, Treasurer). Pokmas account is a joint deposit account between community members in the process of disbursement, payment, and management of development implementation.

In its implementation, Pokmas members must make a power of attorney to Bank BRI to transfer books of funds that exist in individual accounts to Pokmas accounts, in accordance with the applicable disbursement stages. If based on technical and administrative validation found errors in determining the level of damage, as well as data on home ownership and recipients of stimulant assistance, the Head of District / City BPBD makes a revision of the proposed determination and nominal changes to be determined by the Regent / Mayor. The provincial level Verification Team in accordance with field conditions can carry out technical and administrative validation and then make recommendations to the Regent / Mayor to make revisions. If based on the results of validation it turns out that it is not entitled to stimulant assistance for damaged home repairs, the money that has entered the community account can be withdrawn to the BPBD account to 
Effectiveness Of The Performance Of The Blood Management Agency (Bpbd) In Treatment Of

Post Earthquake Natural Disaster In Lombok Province Nusa Tenggara Barat.

be allocated to other eligible recipients according to the decision of the Regent / Mayor.

\section{Process of Analysis Regarding Effectiveness Analysis}

\section{a. Achievement of Regional Strategic Performance}

The NTB Province Regional Disaster Management Agency as a Government agency that handles mandatory basic services has set an annual performance plan and targets. In particular, related to the strategic performance targets of Tangguh Bencana Village and Disaster Safe Schools adjusted to the NTB Province RPJMD 2013 - 2018.

Targets: Realization of Resilient Disaster Villages and the Realization of Communities and Realization of Communities that are aware and responsive to disasters, with indicators of increasing percentage of Resilient Disaster Villages and Disaster Safe Schools, In NTB Provincial Government RPJMD 2013 - 2018, Regional Performance Indicators in terms of Peace and Public Order and the Community Protection that is the responsibility of the NTB Provincial Disaster Management Agency is the percentage of Resilient Disaster Villages and Disaster Safe Schools that are being implemented increasingly.

b. Achievement of Organizational Performance

In addition to the strategic objectives of the Formation of Resilient Disaster Villages and Disaster Safe Schools as listed in the RPJMD 2013 - 2018; The NTB Province Regional Disaster Management Agency also sets organizational performance targets, as further elaboration of the 2018 Annual Performance Plan.

The targets achieved by the NTB Province Regional Disaster Management Agency can be seen from the performance indicators of each strategic target.

\section{Performance Preparation}

Until now, the Regional Disaster Management Agency (BPBD) of West Nusa Tenggara province along with the ranks of BPBDs in each City / District affected by the earthquake in NTB continue to do their utmost in conducting Rehabilitation 
Jurnal Politico Vol. 19 No. 1, Maret 2019

Halaman 50-66. ISSN : p: 1829-6696, e:2549-4716

Web jurnal online: jurnal.unmuhjember.ac.id

By: Faisal Al Riza, Emy Kholifah R.

Effectiveness Of The Performance Of The Blood Management Agency (Bpbd) In Treatment Of

Post Earthquake Natural Disaster In Lombok Province Nusa Tenggara Barat.

and Reconstruction to restore the living conditions of the people. This is also supported by related agencies such as the PUPR Task Force, the TNI through the Integrated Joint Task Command (Kogasgabpad), and BRI Bank which have jointly worked together to carry out development in order to create conducive and stable conditions.

Construction continues to be carried out, verification, cleaning and construction of earthquake-resistant houses have entered a positive development. Based on data compiled by the PUPR Task Force, until now houses have been verified as houses with severe damaged conditions totaling 73,426 housing units, with details in regions per regency / city such as KLU as many as 44,014 units, Lobar with 13,942 units, Lotim with 6,781 units, Lofts 2,884 units, Mataram 2,396 units, Sumbawa Regency 2,169 units, and West Sumbawa Regency 1,240 units.

And according to interviews with residents regarding the performance of the West Nusa Tenggara Provincial Disaster Management Agency in post-earthquake disaster management, namely:

"In my opinion, as residents affected by this natural disaster, BPBD's own performance has been effective, because it has been seen from its performance starting from the formation of community groups to facilitator recruitment whose purpose is to accelerate reconstruction and rehabilitation after this earthquake." (February 25, 2019, 10.00 Wita, Kabupaten West Lombok).

Facilities and infrastructure

The reconstruction and rehabilitation consists of rebuilding infrastructure and facilities, rebuilding community social facilities, rebuilding the socio-cultural life of the community, implementing appropriate design and use of better equipment and disaster resilience, participation and participation of social institutions and organizations, the world business and society, improving social, economic and cultural conditions, improving the function of public services, and improving the main services in the community.

Regarding post-earthquake disaster management facilities and infrastructure, Ir. H. Muhammadin explained that: 
"In an emergency, the most important thing is the availability of clean water and sanitation facilities and infrastructure for daily necessities for victims and refugees as well as for the tents. Regarding the primary infrastructure facilities have been carried out and we as the NTB provincial BPBD themselves also continue the survey action to find out which areas have not been touched by these facilities and infrastructure. (February 23, 2019, 10:00 WITA at NTB Province BPBD Office)

\section{Monitoring and Control System}

\section{A. Technical Supervision}

Supervision of the implementation of Disaster Victims Home Improvement is carried out by the Regency / City BPBD and the Regency / City technical team to ensure the implementation of work in accordance with planning, timely and accountable. District / City BPBD involves NTB Representative BPKP, BNPB Main Inspectorate, and or TP4D involving Provincial / District / City Inspectorates.

B. Administration, Reporting and Accountability

1. Administration

Regional Government in this case BPBD regency / city organizes administration, accounting and reporting activities regularly in accordance with BNPB Regulation number 2 of 2018 and Regulation of the Minister of Finance Number 105 / PMK.05 / 2013.

\section{Reporting}

Reports on the implementation of Disaster Victim Home Improvement activities sourced from BNPB's DSP are submitted by the Regent / Mayor and Governor to the Head of BNPB on a monthly basis as a material for monitoring and evaluation and the final report on the implementation of Disaster Victims Home Improvement in accordance with statutory regulations. Periodic and tiered reporting consists of periodic reports and final reports, namely,

a. Weekly report 
Weekly Contains a collection of damaged house repair activities made by the Pokmas and known to the Facilitator.

b. Monthly Reports include:

1. The Work Progress Report made by the Pokmas, which was submitted to PPK

2. Report on the Progress of Implementation of Activities made by the Head of the BPBD to the Regent / Mayor

3. Report on the Progress of the Implementation of Activities made by the Governor and Regent / Mayor submitted to the head of BNPB

c. The Final Report includes:

1. Completed Work Report made by the Pokmas to PPK after the work is completed $100 \%$

2. Completed Work Report made by the head of the BPBD to the Regent after the work is completed $100 \%$

3. Completed Work Report made by the Governor / Mayor submitted to the head of BNPB.

\section{Accountability}

Accountability of Stimulant Assistance for Disaster Victims Home Improvement from DSP BNPB follows the DSP management mechanism regulated by BNPB Regulation Number 2 Year 2018 concerning the Use of Ready-to-Use Funds, which is no later than 3 months after the disaster emergency status period ends.

Financial expenditures and liabilities sourced from APBD funds follow the provisions of the APBD accountability in Permendagri 13 of 2006. Funding for Disaster Victim Home Improvement activities originating from other sources will account for the provisions that govern them.

C. Control

1. Monitoring and Evaluation 
Monitoring and evaluation is carried out to ensure that the objectives of Disaster Victim Home Improvement activities can be achieved efficiently, effectively, and accountably and in accordance with applicable regulations.

Monitoring is an activity to find out and monitor and record the preparation and implementation (development) of fund management and Disaster Victim Home Improvement activities as planned.

Monitoring aims to ensure that:

a. The strategic policy points and priority plans have been implemented consistently

b. The management of home emergency repair funds has been carried out efficiently and effectively as well as obeying the applicable statutory provisions in achieving the objectives of its activities.

In carrying out the monitoring, identification of the problems is also carried out, which is then discussed with the problems faced in order to obtain relevant solutions to be implemented in achieving the objectives of the activity. Monitoring is carried out periodically on a monthly, quarterly or semester basis.

The evaluation was carried out at the end of the activity, carried out to assess the extent to which the activity objectives had been achieved in accordance with the original plan and to facilitate all stakeholders in assessing and correcting the impact of Disaster Victims Home Improvement activities on the recovery of people's lives in the affected areas. Methods and indicators for monitoring and evaluation have begun to be determined when planning begins to be compiled.

Monitoring and evaluation is carried out on all construction and nonconstruction activities from the preparation process to the completion of the activities. The monitoring and evaluation are as material for assessing the performance of the implementation of Disaster Victim Home Improvement.

\section{Supervision}

The supervisory activities in question are supervision of the implementation of Disaster Victim Home Improvement activities with the aim of 
Jurnal Politico Vol. 19 No. 1, Maret 2019

Halaman 50-66. ISSN : p: 1829-6696, e:2549-4716

Web jurnal online: jurnal.unmuhjember.ac.id

By: Faisal Al Riza, Emy Kholifah R.

Effectiveness Of The Performance Of The Blood Management Agency (Bpbd) In Treatment Of

Post Earthquake Natural Disaster In Lombok Province Nusa Tenggara Barat.

reducing or avoiding problems related to abuse of authority and all other forms of irregularities, which can result in waste and / or loss of state finances.Supervision includes inherent supervision, functional supervision (external and internal areas), and community supervision.

a. Supervision attached

Adherent supervision is carried out by the leadership of his subordinates in each work unit on the implementation of Disaster Victim Home Improvements using DSP funds.

b. Functional Supervision

The authority to carry out supervision includes checks carried out by external and internal parties in accordance with applicable laws and regulations.

c. Community Oversight

The community also has the right / obligation to supervise the implementation of Disaster Victim Home Improvement activities. If there are indications of irregularities in the implementation of the said activity, then the public can report it to the competent authority.

Reports from the public must be responded to proportionally by the provincial BPBD and the regency / city BPBD whose people received the Stimulant Relief Aid for Disaster Victim Home Improvement.

The provincial / district / city government needs to provide facilities that can accommodate questions / complaints from the public and establish a mechanism for resolving the problems submitted by the community.

\section{CONCLUSION}

1. Performance of the West Nusa Tenggara Provincial Disaster Management Agency in post-earthquake disaster management is engaged in reconstruction and rehabilitation in the form of stimulant assistance to repair homes for disaster victims

2. The performance measurement system for the effectiveness of the current Regional Disaster Management Agency uses the Government Agency 
Performance Accountability Report (Lakip), this system is considered to be less effective because the Lakip system only focuses on organizational achievements without being involved in improving organizational performance.

3. The performance measurement system currently in use is not yet a measurement system that is integrated with the organization's strategic goals. An effective performance measurement criterion is a measurement system based on the goals and vision and mission of the organization.

4. From the five stages of performance measurement it can be concluded that in the NTB Province BPBD:

a. Preparation of a Work Plan

The NTB Province BPBD has compiled a work plan which is derived from the NTB Province's strategic plan and the work plan prepared also based on the NTB Province's BPBD vision and mission

b. Strategic Goals

The realization of strategic targets that have been programmed in disaster management after the earthquake in Lombok effectively and the availability of supporting facilities and infrastructure.

c. Indicator of Achievement

The achievement indicator itself has become the performance agreement of the Governor of NTB with the NTB BPBD which made a reference for the effectiveness of performance in post-earthquake disaster management, namely:

1. The establishment of a disaster-resilient village

2. Logistical needs

3. Report on monitoring and evaluation

4. Safe school disaster

5. Improved communication and information

6. Infrastructure

3. Analysis of work 
Jurnal Politico Vol. 19 No. 1, Maret 2019

Halaman 50-66. ISSN : p: 1829-6696, e:2549-4716

Web jurnal online: jurnal.unmuhjember.ac.id By: Faisal Al Riza, Emy Kholifah R.

Effectiveness Of The Performance Of The Blood Management Agency (Bpbd) In Treatment Of

Post Earthquake Natural Disaster In Lombok Province Nusa Tenggara Barat.

Analysis of the work at the NTB Province BPBD is contained in a document called job analysis, but the document is not used as one of the elements in the preparation of a performance measurement system.

4. Policy

The NTB Province BPBD policy in post-earthquake disaster management has been carried out in the form of coordination and consultation with the affected areas, BNPB, NTB BPBD, and local governments. 
Jurnal Politico Vol. 19 No. 1, Maret 2019

Halaman 50-66. ISSN : p: 1829-6696, e:2549-4716

Web jurnal online: jurnal.unmuhjember.ac.id

By: Faisal Al Riza, Emy Kholifah R.

Effectiveness Of The Performance Of The Blood Management Agency (Bpbd) In Treatment Of

Post Earthquake Natural Disaster In Lombok Province Nusa Tenggara Barat.

\section{References}

Kusumajati, Luthfiana dan, Dra. Hj. Sri Arfiah, S.H., M.Pd. (2016) Peranan

Bpbd Dalam Penanggulangan Bencana Alam Di Desa Windurejo

Kecamatan Kesesi Kabupaten Pekalongan. Skripsi thesis, Universitas

Muhammadiyah Surakarta.

Sari, Nurkumala (2014) Implementasi Tugas dan Fungsi Badan Penanggulangan

Bencana Daerah (BPBD) Kabupaten Maros. Skripsi, Universitas

Hasanuddin Makasar.

Rahmadhan, Ilham dan, Armansyah Martondang (2016) Peran Badan

Penanggulangan

Bencana Daerah Kota Medan Dalam Penanggulangan Bencana. Jurnal, Universitas Medan Area.

Lie, Melati (2015) Efektivitas Pengukuran Kinerja Badan Kepegawaian Daerah Kota Palopo. Skripsi, universitas hasanuddin Makasar.

Dani Suhend . Konsep efektivitas. Dikutip 22 Desember 2018 dari :

http://eprints.umm.ac.id/35927/3/jiptummpp-gdl-danisuhend-48876-3-

babii.pdf

Siagian, Sondang P. (2001) Buku Manajemen Sumber daya Manusia Volume 4.

Bumi Aksara.

Wikipedia. Gempa Bumi. Dikutip 22 Desember 2018 dari

:https://id.wikipedia.org/wiki/Gempa_bumi 